\title{
Hop-on, hop-off: the first record of the alien species crescent- marked lily aphid (Neomyzus circumflexus) (Insecta, Hemiptera, Aphididae) in Greenland
}

\author{
Karina Wieczorek (1) \& Dominik Chłond (1) \\ Institute of Biology, Biotechnology and Environmental Protection, Faculty of Natural Sciences, University of Silesia in Katowice, Katowice, Poland
}

\begin{abstract}
We report for the first time the presence of the globally distributed and extremely polyphagous pest species-the crescent-marked lily aphid (or mottled arum aphid) (Neomyzus circumflexus L.) (Insecta, Hemiptera, Aphididae)-in Greenland. This species, of alien origin, was found on the ornamental plant Salix arbuscula L., imported from Denmark and sold in the main supermarket of Nuuk, the capital of Greenland. As this species is not the preferred host plant of $N$. circumflexus, the possibility must be considered that the aphids were not imported along with $S$. arbuscula from the mainland but were transferred from other imported ornamental plants sold in the store. Supermarkets selling decorative plants may be becoming reservoirs of alien species, facilitating the movement of aphids and other alien species that "hop on, hop off," to borrow a phrase from the tourism industry. As unintentional introductions present the greatest threats to the Arctic ecosystems, a stricter approach to regional biosecurity needs to be considered and non-native species control and eradication should be implemented.
\end{abstract}

\section{Keywords}

Biological invasion; Low Arctic; Macrosiphini; pathway of introductions; pest species; Salix arbuscula

\section{Correspondence}

Karina Wieczorek, Institute of Biology, Biotechnology and Environmental

Protection, Faculty of Natural Sciences, University of Silesia in Katowice, Bankowa 9, PL-40-007 Katowice, Poland. E-mail: karina. wieczorek@us.edu.pl

\section{Abbreviations}

DZUS: Zoology Unit, University of Silesia in Katowice ; INTERACT: European Union project International Network for Terrestrial Research and Monitoring in the Arctic

\section{Introduction}

Aphids (Insecta, Hemiptera, Aphididae) are among the most dangerous and most common pests of economic importance (van Emden \& Harrington 2017). Among them, the species of non-native origin play a special role (Couer d'Acier et al. 2010). In new areas, and under favourable conditions, they can become invasive or can attack native and endemic plants (Wieczorek et al. 2019). Unintentional introductions present the greatest threats to Arctic ecosystems (Ware et al. 2011; Ware et al. 2014; Alsos et al. 2015; Ware et al. 2016). The geographical location of Greenland, the world's largest island, makes it particularly vulnerable to the appearance of alien species. The current aphid fauna of Greenland comprises relatively few taxa. Approximately 20 species have been recorded so far, mostly along the west coast. Most of them have a circumpolar distributional range; a limited number of species are treated as endemic (Hille Ris Lambers 1952, 1960; Heie 2015). Non-native species of this group of insects have not been recorded so far in Greenland. As climate change alters Arctic ecosystems and enables greater human activity, biological invasion in the Arctic is likely to increase.

During the investigation, which was conducted in July 2019, we had the opportunity to collect aphids in Nuuk, the capital of Greenland. One of the results of our field study was the first detection on the island of the alien aphid species Neomyzus circumflexus L.

\section{Materials and methods}

Nuuk $\left(64^{\circ} 10^{\prime} \mathrm{N} 51^{\circ} 44^{\prime} \mathrm{W}\right)$ is the most highly populated city and the capital of Greenland, located in the Low Arctic. The surveys that are reported here were carried out in the city and its vicinity. The investigation was conducted in July 2019. The aphids were collected directly from the host plants with a fine brush and placed into Eppendorf tubes containing 70\% ethanol. Adult wingless females were prepared before being mounted on slides using the following protocol of aphid preparation: (1) while the aphid was immersed in $70 \%$ ethanol, its body walls were pierced with a sharp needle. (2) The aphid was then placed in $10 \%$ caustic 
potash, also known as potassium hydroxide, in the first of three cavities in a porcelain plate and kept there for 24 hours. After this maceration, all tissue was easily removed with a needle. (3) The aphid was transferred into the second cavity with chloralphenol (a 1:1 mix by weight of chloral hydrate and liquid phenol) and remained there for four to five hours. (4) The aphid was moved into the third cavity of the plate where it was immersed in chloral hydrate for 18-20 hours. The clear and transparent specimen was then ready for the final mount in Berlese fluid (gum chloral) on a microscopic slide. Although not quick, this method has the advantage of being relatively gentle on the fragile aphid body. Because the porcelain plates are enclosed in an airtight container, the method carries few risks for laboratory workers; moreover, it does not require sophisticated equipment.

The slides were examined using a Nikon Ni-U light microscope equipped with a phase contrast system. Field photographs were taken using an iPhone 7 camera with the OlloClip Macro Pro Lens Set. Samples were identified by the first author to the species level based on their morphological diagnostic features, using the standard literature-based keys (Blackman \& Eastop 2006, 2019; Blackman 2010).

Material collected and examined. Nuuk, Greenland, 06.07.2019, two apterous viviparous females from Salix arbuscula, (K. Wieczorek leg.), DZUS 6/7.19_1; Nuuk, Greenland, 06.07.2019, two apterous viviparous females from Salix arbuscula, (K. Wieczorek leg.), DZUS 6/7.19_2; Nuuk, Greenland, 06.07.2019, one apterous viviparous female from Salix arbuscula, (K. Wieczorek leg.), DZUS 6/7.19_3.

The aphid material has been deposited in the collection of the Zoology Unit at the University of Silesia in Katowice, Poland

\section{Results and discussion}

Living specimens of a virginoparous generation of Neomyzus circumflexus were collected from plants sold in the main supermarket of Nuuk. Aphids were found only on the stem of young shoots on two individuals of Salix arbuscula L. (Fig. la). The aphids were clearly visible, but dispersed, not forming a solid colony (Fig. lb). Only wingless adult morphs and numerous immatures were observed. The adult wingless morphs, numbering about 20, were shiny and pale yellow, with distinctive sclerotic dorsal markings consisting of transverse bands or paired patches on the thorax and a large, roughly
U-shaped patch on the abdomen. The immature individuals were also pale yellow. The distinctive dark pattern on the dorsal side of the abdomen of wingless viviparous females (Fig. 1c, d) makes this species easily recognizable.

The infected plants were imported from Denmark and the supermarket staff who are responsible for live green plants did not register the presence of aphids. No additional records of $N$. circumflexus in the studied area were found.

Aphids are strictly associated with their host plants. The presence of the host plant determines the presence of aphids. However, numerous alien aphid species of pest status are polyphagous generalists, globally distributed (Blackman \& Eastop 2000, 2006; van Emden \& Harrington 2017). Neomyzus circumflexus, also known as the crescent-marked lily aphid or mottled arum aphid, is an example of an extremely polyphagous species that is associated with native and cultivated plants, both angiosperms and conifers as well as ferns. In temperate regions it is a serious pest of glasshouse ornamental plants, causing direct feeding damage, growth of black sooty moulds and transmission of some plant viruses (Martin 2017). Moreover, it is an anholocyclic species, without a sexual phase during its life cycle (Blackman \& Eastop 2019), which favours its spread.

Salix arbuscula, the mountain willow, is a low, much branched shrub having a limited distribution in northern Europe, occurring from northern Scandinavia eastwards to Siberia (Scottish Montane Willow Research Group 2005). It is also sold as an ornamental plant. It is not the preferred host plant of $N$. circumflexus (Blackman \& Eastop 2019), making it unlikely that the aphids were imported along with this host plant from the mainland; they were more likely transferred from other ornamental plants sold in the store. Several decorative imported species-including more preferred host plants such as Cyclamen sp., Ficus sp., Fuchsia sp. and Oxalis sp.-were stored in the same place, facilitating the movement of aphids. We observed a similar situation in Longyearbyen (the Svalbard Archipelago, Norway) in 2018 (Wieczorek \& Chłond 2019), where three ornamental plants infected by the alien aphid species Myzus (Nectarosiphon) persicae (Sulzer) were displayed in front of one of the shops in the main street of the town. The source of the plants was Svalbard's only supermarket, which had brought them from the mainland of Norway. Our observations in Nuuk and Longyearbyen suggest that supermarkets selling decorative plants are becoming reservoirs of alien species.

Both in Longyearbyen and Nuuk, the combination of factors, such as a relatively large diversity of native 


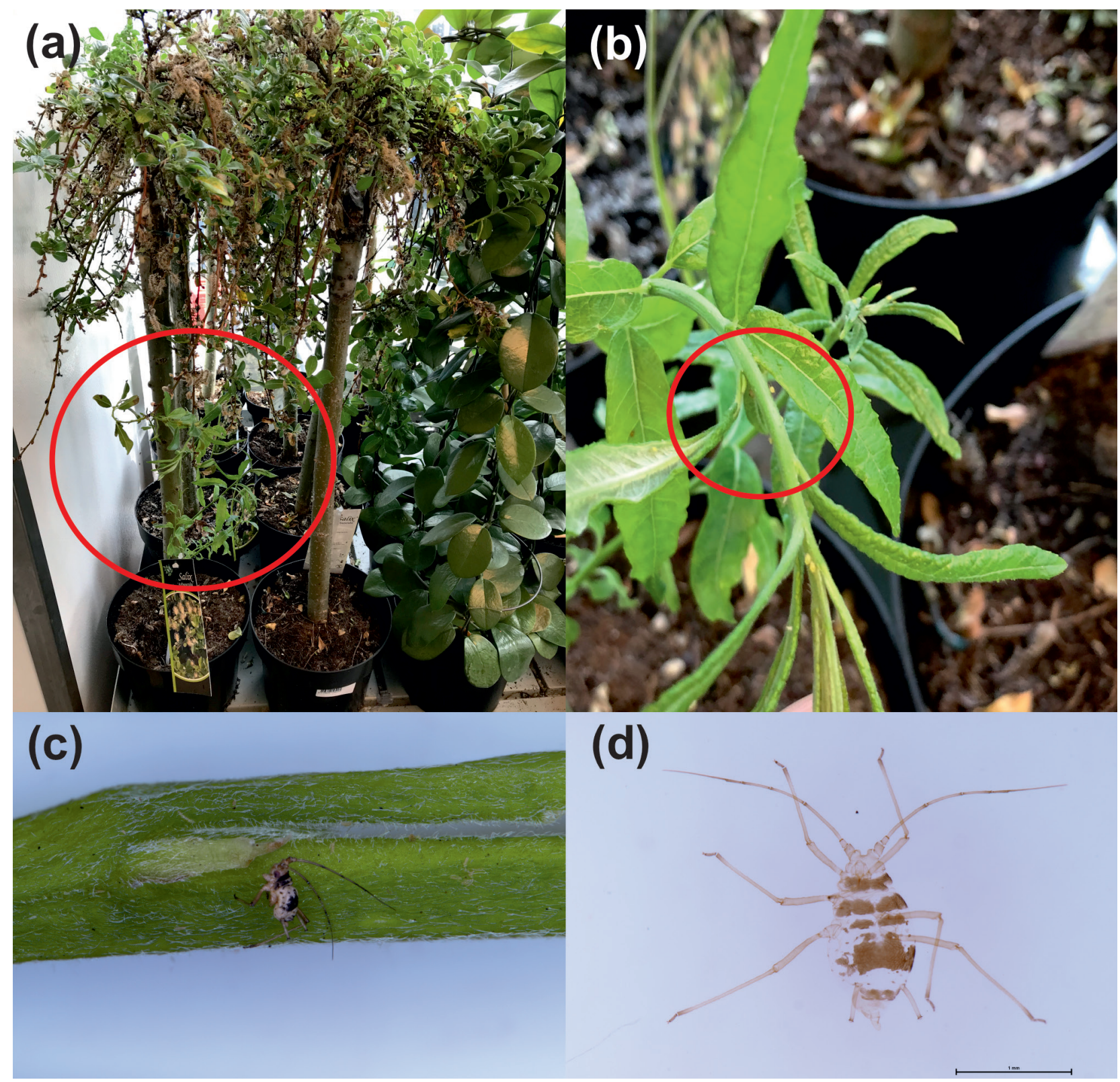

Fig. 1 (a-c) Wingless viviparous females of the crescent-marked lily aphid (Neomyzus circumflexus) and its host plant Salix arbuscula; (d) slide-mounted specimen of $N$. circumflexus.

plants, the short distance to the airport, seaport and human population density, promotes the introduction, settlement and spread of insect species of foreign origin, including aphids. Regardless of whether these species will be able to successfully overwinter outdoors (at least three native anholocyclic species are known from Greenland), our results, supported by other studies (Bacon et al. 2012), suggest that a stricter approach to regional biosecurity needs to be considered in order to avoid the risks of further unintentional introductions.
According to the Arctic Invasive Alien Species Strategy and Action Plan (2017), prepared by the Arctic Council working groups Conservation of Arctic Flora and Fauna and Protection of the Arctic Marine Environment, early detection and response to an alien species before it becomes established and causes harm is a necessary step to protect the fragile Arctic ecosystems. In this context, our basic study using simple tools is an effective method that fits into the strategy of early warning in the Arctic. 


\section{Disclosure statement}

The authors report no potential conflict of interest.

\section{Funding}

This research has received funding from the European Union's Horizon 2020 project INTERACT under grant agreement no. 730938 .

\section{Acknowledgements}

The authors thank Hannele Savela, Coordinator, INTERACT Transnational Access, and Katrine Raundrup, INTERACT Station Manager, Greenland Institute of Natural Resources, Nuuk, Greenland. They are also grateful to the anonymous reviewers for their valuable comments during the review process.

\section{References}

Alsos I.G., Ware C. \& Elven R. 2015. Past Arctic aliens have passed away, current ones may stay. Biological Invasions 17, article no. 3113 , doi: 10.1007/s10530-015-0937-9.

Bacon S.J., Bacher S. \& Aebi A. 2012. Gaps in border controls are related to quarantine alien insect invasions in Europe. PLoS One 7(10), e47689, doi: 10.1371/journal.pone.0047689.

Blackman R.L. 2010. Aphids-Aphidinae (Macrosiphini). Handbook for identification of British insects. St Albans: Royal Entomological Society.

Blackman R.L. \& Eastop V.F. 2000. Aphids on the world's crops. An identification and information guide. 2nd edn. Chichester: John Wiley \& Sons.

Blackman R.L. \& Eastop V.F. 2006. Aphids on the world's herbaceous plants and shrubs. Chichester: John Wiley \& Sons.

Blackman R.L. \& Eastop V.F. 2019. Aphids of the world's plants: an online identification and information guide. Accessed on the internet at http://www.aphidsonworldsplants.info on 3 September 2019

CAFE-PAME (Conservation of Arctic Flora and Fauna / Protection of the Arctic Marine Environment) 2017. Arctic invasive alien species: strategy and action plan. Akureyri: Conservation of Arctic Flora and Fauna / Protection of the Arctic Marine Environment.

Couer d'Acier A., Pérez Hidalgo N. \& Petrović-Obradović O. 2010. Aphids (Hemiptera, Aphididae). BioRisk 4(1), 435-474, doi: 10.3897/biorisk.4.57.

Heie O.E. 2015. Aphidomorpha. In J. Böher et al. (eds.): The Greenland entomofauna. An identification manual of insects, spiders and their allies. Fauna Entomologica Scandinavica. Vol. 44. Pp. 121-131. Leiden: Brill.

Hille Ris Lambers D. 1952. The aphid fauna of Greenland. Meddelelser om Grönland 136. Copenhagen: C.A. Reitzel.

Hille Ris Lambers D. 1960. Additions to the aphid fauna of Greenland. Meddelelser om Grönland 159. Copenhagen: C.A. Reitzel.

Martin N.A. 2017. Lily aphid-Neomyzus circumflexus. Interesting insects and other invertebrates. New Zealand Arthropod Factsheet Series Number 118. Accessed on the internet at http://nzacfactsheets.landcareresearch.co.nz/ Index.html on 3 September 2019.

Scottish Montane Willow Research Group 2005. Biodiversity: taxonomy, genetics and ecology of sub-Arctic willow scrub. Edinburgh: Royal Botanic Garden.

van Emden F. \& Harrington R. 2017. Aphids as crop pests. London: CABI Publishing.

Ware C., Berge J., Jelmert A., Olsen S.M., Pellissier L., Wisz M., Kriticos D., Semenov G., Kwaśniewski S. \& Alsos I.G. 2016. Biological introduction risks from shipping in a warming Arctic. Journal of Applied Entomology 53, 340-349, doi: 10.1111/1365-2664.12566.

Ware C., Berge J., Sundet J.H., Kirkpatrick J.B., Coutts A.D.M., Jelmert A., Olsen S.M., Floerl O., Wisz M.S. \& Alsos A.G. 2014. Climate change, non-indigenous species and shipping: assessing the risk of species introduction to a High-Arctic archipelago. Diversity and Distribution 20, 10-19, doi: 10.1111/ddi.12117.

Ware C., Bergstrom D.M., Müller E. \& Alsos I.G. 201 1. Humans introduce viable seeds to the Arctic on footwear. Biological Invasions 14, 567-577, doi: 10.1007/s10530-011-0098-4.

Wieczorek K. \& Chłond D. 2019. The first detection of the alien species-green-peach aphid Myzus (Nectarosiphon) persicae (Insecta, Hemiptera, Aphididae) in the Svalbard Archipelago. Polar Biology 42, 1947-1951, doi: 10.1007/s00300-019-02562-9.

Wieczorek K., Fulcher T. \& Chłond D. 2019. The composition of the aphid fauna (Insecta, Hemiptera) of the Royal Botanic Gardens, Kew. Scientific Reports 9, article no. 10000, doi: 10.1038/s41598-019-46441-z. 